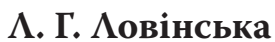

доктор економічних наук, професор, заступник директора з наукової роботи НДФІ ДННУ“Академія фінансового управління”, Київ, Україна, lovinska@ukr.net ORCID ID: https://orcid.org/0000-0001-5427-7185

\section{Я. В. ОАійник}

доктор економічних наук, доцент, директор Інституту післядипломної освіти ДННУ “Академія фінансового управління”, Київ, Україна, oleynik_yv@ukr.net ORCID ID: https://orcid.org/0000-0001-5895-282X

\section{М. В. Кучерява}

кандидат економічних наук, в. о. завідувача відділу методології бухгалтерського обліку НДФІ ДННУ “Академія фінансового управління”, Київ, Україна, piven_maria@ukr.net ORCID ID: https://orcid.org/0000-0003-2948-1234

\section{МЕТОАИЧНІ ПІАХОАИ АО ОЦІНКИ ВНЕСКУ КОМПАНІЙ

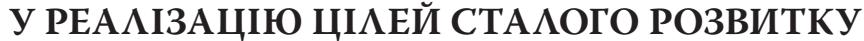 ТА ПРОТИАІЮ СОVID-19}

Анотація. У статті розглянуто методичні підходи щодо вдосконалення нефінансової звітності піАприємств України в контексті імплементації положень Керівництва 3 кАючових показників звітності піАприємств щодо внеску у реалізацію Цілей сталого розвитку, виданого ЮНКТАА, у частині вкцаАу приватного сектору в Аосягнення ЦСР та відображення насліАків пандемії COVID-19. Обгрунтовано, що перелік показників, визначений цим документом, є еталоном Аля оцінки внеску компаній у реацізацію ЦСР і може бути покмаАений в основу розкриття інформації у звіті про управління. За результатами досліАження сформульовано інституціональні підвалини вдосконалення складання нефінансової звітності в умовах кризи, спричиненої пандемією, за Аопомогою аналізу міжнародних ініціатив. Це Аало змогу розробити пропозиції щодо вкАючення Аодаткових показників у звіт про управ інняя в частині розкриття інформації про вплив COVID-19 на Аія ьнність піАприємств та їх внесок у протиАію поширенню захворювання.

Кмючові слова: сталий розвиток, звіт про управління, ЮНКТАА, Аиректива 2014/34/EC, COVID-19.

Табц. 1. Аіт. 26.

\section{Liudmyla Lovinska}

Dr. Sc. (Economics), Professor, SESE "The Academy of Financial Management",

Kyiv, Ukraine, lovinska@ukr.net

ORCID ID: https://orcid.org/0000-0001-5427-7185

\section{Yana Oliinyk}

Dr. Sc. (Economics), Associate Professor, SESE "The Academy of Financial Management",

Kyiv, Ukraine, oleynik_yv@ukr.net

ORCID ID: https://orcid.org/0000-0001-5895-282X

\section{Maria Kucheriava}

Ph. D. (Economics), SESE "The Academy of Financial Management",

Kyiv, Ukraine, piven_maria@ukr.net

ORCID ID: https://orcid.org/0000-0003-2948-1234

\footnotetext{
${ }^{1}$ Статтю підготовмено в рамках проекту, що виконується за грантової підтримки Націона ьного фонду Аосліджень України (реєстраційний номер: 2020.01/0546).

(c) Аовінська А. Г., ОАійник Я. В., Кучерява М. В., 2020
} 


\title{
METHODOLOGICAL APPROACHES TO ASSESSING COMPANIES CONTRIBUTION TO THE IMPLEMENTATION OF SDGS AND COUNTERACTION TO COVID-19
}

\begin{abstract}
The methodological approaches to improving the non-financial reporting of Ukrainian enterprises in the context of implementing the provisions of the document issued by UNCTAD (GCI), in terms of the private sector's contribution to the COVID-19 are highlighted. The authors identified the lack of unified approach to the standardization of non-financial reporting and the harmonization of companies' core indicators with macro-indicators of SDGs' achievement in the relevant areas. The hypothesis of the study: the GCI as an effective tool to ensure comparability of information disclosed in nonfinancial statements between companies, industries, geographical areas, countries, can be used to quantify core indicators that should be disclosed by Ukrainian companies for providing the information suport for SDGs monitoring. The purpose of the study is to substantiate information support and assessment of business contribution to process of SDGs' monitoring and overcoming the effects of the COVID-19 pandemic, including indicator 12.6.1, by defining the limited list of universal indicators within the national legislation, GCI recommendations and initiatives aimed at disclosure of coronavirus disease's impact on the company's activities. The authors within the study proved that the application of core indicators suggested by the GCI would not only promote the level of data transparency on the impact of reporting entities, but also provide the opportunity to compare information between companies, industries, geographical areas, countries. Based on the results of the study and conducted analysis of international initiatives, the institutional basis for improving the preparation of non-financial reporting within the crisis caused by the COVID-19 pandemic was formulated. This allowed to substantiate the suggestion on inclusion of additional indicators in the management report in terms of disclosing information about the impact of the COVID-19 pandemic on the activities of enterprises and their contribution to combating the spread of the disease.
\end{abstract}

Keywords: sustainable development, management report, UNCTAD, Directive 2013/34/ EU, COVID-19.

JEL classification: M41, O32.

\section{$\Lambda$. Г. Аовинская}

доктор экономических наук, профессор, заместитель директора по научной работе НИФИ ГУнУ “Академия финансового управления", Киев, Украина

\section{Я. В. Омейник}

доктор экономических наук, доцент, директор Института последипломного образования ГУнУ “Академия финансового управления", Киев, Украина

\section{М. В. Кучерявая}

кандидат экономических наук, и. о. заведующего отделом методологии бухгалтерского учета НИФИ ГУНУ “Академия финансового управления", Киев, Украина

\section{МЕТОАИЧЕСКИЕ ПОАХОАЫ К ОЦЕНКЕ ВКАААА КОМПАНИЙ В РЕААИЗАЦИЮ ЦЕАЕЙ УСТОЙЧИВОГО РАЗВИТИЯ И ПРОТИВОАЕЙСТВИЕ СОVID-19}

Аннотация. В статье рассмотрены методические подходы к усовершенствованию нефинансовой отчетности предприятий Украины в контексте имплементации поможений Руководства по ключевым показателям отчетности предприятий касательно вкцада в реализацию Целей устойчивого развития, изАанного ЮНКТАА, в части вкцаАа частного сектора в Аостижение ЦУР и отображения послеАствий пандемии COVID-19. Обосновано, что перечень показателей, определенный этим 
Аокументом, яв яется эталоном Аля оценки вкцаАа компаний в реацизацию ЦУР и может быть положен в основу раскрытия информации в отчете об управлении. По результатам исследования сфомулированы институциональные основы усовершенствования составления нефинансовой отчетности в условиях кризиса, вызванного пандемией, с помощью анализа межАународных инициатив. Это позволико разработать преАложения по вкцючению допо нительных показателей в отчет об управ ении в части раскрытия информации о влиянии COVID-19 на Аеяте ьность преАприятий и их вкцаА в противодействие распространению заболевания.

Кмючевые слова: устойчивое развитие, отчет об управлении, ЮНКТАА, Аиректива 2013/34/EC, COVID-19.

На сьогодні налічується більш ніж Ава десятки визнаних міжнародних ініціатив із питань скмадання нефінансової звітності. Кожна з них фокусується на пріоритеті розкриття інформації про економічні, соціальні, екологічні й управлінські компоненти бізнесу. Протягом 2020 р. унаслідок спалаху захворюваності на коронавірус COVID-19 були розроблені нові міжнародні Аокументи, які мають на меті забезпечити розкриття інформації про Аіяльність компаній в умовах пандемії.

СліА зазначити, що новаціям нефінансової звітності притаманні ті самі проблеми, як і традиційним підходам. Зокрема, різноманітність визнаних міжнародних рекомендацій із питань скмадання нефінансової звітності спричиняє продукування величезного масиву інформації, котру неможливо порівнювати між компаніями, гахузями, географічними районами, країнами. Така ситуація помітно утруднює уніфікацію нефінансової звітності компаній та перешкоджає реалізації механізму інформаційного забезпечення визначення країнами індикатора 12.6.1 “Кількість компаній, що публікують звіти зі сталого розвитку" [1], котрий є важливим інструментом оцінки внеску приватного сектору в Аосягнення Цілей сталого розвитку (ЦСР), у т. ч. в умовах пандемії COVID-19.

Водночас безпрецедентна ситуація в новітній історії вимагає реагування й масштабних Аій приватного та державного секторів економік із метою поАолання унікальних викмиків. Очевидно, що жодна країна не зможе вийти 3 кризи вцасними симами та без налагодженої співпраці з бізнесом.

Проблеми, з якими стикаються піАприємства піА час кризи, викмиканої коронавірусною хворобою, перешкоджають їх сталому розвитку. Тож поАа ьші дослідження, пов'язані зі звітністю піАприємств і країн на преАмет Аосягнення ЦСР, Аоцільно спрямовувати на пошук інструментів, що Аопоможуть компаніям у розкритті дотримання принципів сталого розвитку та в боротьбі з кризою, а урядам - більш плідно співпрацювати з бізнесом заАля реалізації ЦСР і подолання негативних явищ у економіці й суспільстві. Такий піАхіА сприятиме соціальній згуртованості завАяки поліпшенню обізнаності щодо міжнародних ініциатив із питань розкриття підприємствами їх реакції на пандемію та забезпечення сталого розвитку.

Останніми роками вдосконалення ініціатив стосовно нефінансового звітування зАійснюється головним чином із метою піАвищення вимог Ао 
прозорості й порівнянності інформації, а також уніфікації підходів Ао іï скмадання. Згадані тренди $\epsilon$ преАметом активного наукового Аискурсу. АосліАжуються шляхи розширення кола об'єктів нефінансової звітності [2; 3], аналізується та критично оцінюється вплив розкриття нефінансової інформації на корпоративну соціальну відповідальність [4-8].

Разом із тим і в науковому, і в професійному середовищі на міждержавному рівні немає єАиного піАходу до уніфікації нефінансової звітності та узгодження кмючових показників компаній із макроіндикаторами досягнення ЦСР у віАповіАних сферах.

Робота з узгодження основних показників досягнення ЦСР ААя компаній із індикаторами їх реалізації на національному й глобальному рівнях тривалий час проводиться в Женеві (Швейцарія) Міжурядовою робочою групою експертів з міжнародних стандартів бухгалтерського обліку і звітності Конференції Генеральної Асамблеї ООН з торгівлі та розвитку (далiISAR-UNCTAD). Ï̈ результатом у сфері скмадання нефінансової звітності стало розроблення й оприлюАнення в травні 2019 р. ініціативи “Керівництво 3 основних показників звітності піАприємств щодо внеску в Аосягнення ЦСР" (Guidance on core indicators for entity reporting on contribution towards implementation of the Sustainable Development Goals; далi - GCI) [9]. Метою GCI $\epsilon$ надання практичної інформації про вимірювання показників досягнення ЦСР у контексті їх узгодження на виконання завдань системи моніторингу ЦСР. Тому саме рекомендації ISAR-UNCTAD $є$ альтернативою Аомінуючому наразі в $\in C$ і в Україні піАходу до розкриття в нефінансовій звітності, зокрема звіті про управління, інформації в довільній формі за самостійно обраним набором показників.

Ініціатива підготовцена на основі вивчення міжнародного Аосвіду та не пропонує нових показників. Вона покмикана допомогти у виборі загальних показників стійкості, виходячи з поточної практики звітування підприємств і провіАних систем звітності (IFRS [10], IIRC [11], SASB [12], GRI [13] та ін.). Важливою особливістю GCI $€$ те, що нею пропонується методологія вимірювання кожного показника та рекомендуються Ажерела збору Ааних Аля розрахунку. При цьому всі показники GCI кількісні, що скугує запорукою їх порівнянності по окремих піАприємствах, уможливлює їх консоліАацію за галузями, країнами, на глобальному рівні.

При розробленні GCI показники обиралися за такими критеріями: віАповіАність хоча 6 одному індикатору моніторингу ЦСР; базування на наявних ключових ініціативах або системах звітності та/або наявність у корпоративних звітах; універсальність (можливість застосування до всіеї звітності підприємства); порівнянність між галузями; можАивість послідовного

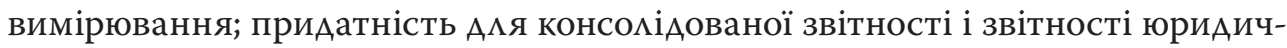
них осіб; наявність методології вимірювання й порівнянності даних, чітких рамок звітності та поступового піАхоАу [9].

Викладене дає підстави вважати перелік показників GCI наразі еталоном для оцінки внеску компаній у досягнення ЦСР $і$ визнати ініциативу 
GCI визначальною з метою вдосконалення національного законодавства 3 питань небінансового звітування. Аоречність обрання GCI як еталонного піАходу піАтверАжується й тим, що такий самий напрям удосконалення нефінансової звітності обрано в СС.

У 2017 р. опубціковано Повідомлення Єврокомісії 2017/С 215/01 “Керівництво $з$ нефінансової звітності (методологія звітності з нефінансової інформації)" (далі - Керівництво 2017/C 215/01) [14]. Мета цього документа - Аопомогти піАприємствам у розкритті високоякісної, актуацьної, корисної, більш порівнянної нефінансової інформації (екологічної, соціальної, управлінської) у спосіб, який сприятиме стійкому і стабільному зростанню та зайнятості й надаватиме користувачам прозору інформацію.

Застосування Керівництва 2017/С 215/01 не обов'язкове, а компанії, котрі є суб'єктами скмадання звіту про управління, можуть керуватися при його піАготовці та опримюАненні міжнародними, європейськими або націона ьними стандартами [14]. Тож ухвалення цього Аокумента не стримує інноваційні процеси в практиці звітування.

Керівництво 2017/C 215/01 визначає кмючові показники Аіяльності (Кеу Performance Indicators - KPI) як ефективні інструменти поєАнання кількісної та якісної інформації. КРІ повинні послідовно використовуватися А я звітування компанією, віА оАного звітного періоду Ао іншого (Аця уможАивмення проведення ретроспективного й перспективного анацізу їі розвитку та зміни позиції).

Отже, гіпотезою цього досліАження $є$ тверАження, що GCI як ефективний інструмент забезпечення порівнянності інформації між піАприємствами, галузями, географічними районами, країнами, котра розкривається в нефінансовій звітності, може застосовуватися Аля визначення кцючових кількісних показників, які доцільно розкривати компаніям України заАля сприяння порівнянності даних і інформаційного забезпечення моніторингу ЦСР. ПереАбачається, що показники GCI є універсацьними й актуацьними Аля піАприємств незалежно віА виАу Аіяльності, галузі, країни.

Мета Аослідження полягає в обгрунтуванні інформаційного забезпечення та оцінки впливу бізнесу в процесі моніторингу ЦСР і подолання насліАків COVID-19, зокрема індикатора 12.6.1, шияхом визначення обмеженого переліку універсацьних показників із урахуванням норм націона ьного законодавства, рекомендацій GCI та ініциатив, спрямованих на розкриття вп иву на Аія ьність піАприємств коронавірусної хвороби.

Україна $є$ членом ООН і учасницею глобамьного процесу реалізації ЦСР. Водночас, з огляду на вектор їі розвитку, нею взято зобов'язання щодо поступового наближення націонацьного законодавства Ао європейського, зокрема за рахунок імплементації положень Аирективи 2013/34/ЄС. ЗаАля цього у 2017 р. внесено зміни до Закону України "Про бухгацтерський облік та фінансову звітність в Україні” віА 16.07.1999 № 996-XIV (далі - Закон № 996-XIV) [15], якими встановцена вимога Аля певних видів підприємств щодо скцаАання звіту про управАіння та консолідованого звіту про управАіння. Законодавчо 
передбачено, що він готується в Аовільній формі. У звіті віАповіАно Ао розміру й скмаАності бізнесу повинен міститися збалансований і комплексний аналіз економічних, екологічних та/або соціальних сфер Аіяльності підприємства, а також змін, котрі сталися в цих сферах протягом року, який минув, і до моменту опублікування річного звіту, та їх можиивого впливу на Аія ьність піАприємства в Аовгостроковій перспективі й потенційних ризиків. Суттєва інформація звіту розкривається через фінансові та нефінансові (за потреби) показники [16].

Зміст звіту про управління визначено Методичними рекомендаціями зі складання звіту про управління, затвердженими наказом Міністерства фінансів України віА 07.12.2018 № 982 (далі - Методичні рекомендації), згіАно 3 якими суттєва інформація розкривається через фінансові й нефінансові (за необхіАністю) показники. Набір індикаторів встанов юється віАповіАно Ао Методичних рекомендацій та/або міжнародних документів, обраних піАприємством Аля збору інформації з метою скмаАання звіту [16].

Окреслені зміни, з одного боку, реалізують підходи законодавства ЄC,

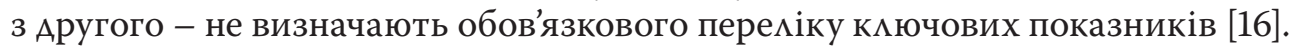
Тож компанії самостійно обирають набір показників згіАно з тим міжнародним Аокументом з розкриття інформації у сфері сталого розвитку, котрому вони віААають перевагу. Як насліАок, показники, що розкриваються у звітності компаній України, помітно різняться залежно віА секторацьної й галузевої специфіки їхньої діяльності.

Застосування 33 показників, пропонованих GCI, Аля скмадання звітності про сталий розвиток забезпечує максимально можмивий ступінь станАартизації національних даних і сприяє їх міжнародній порівнянності. Таке тверАження $є$ слушним, як уже наголошува ося, з огляду на універсацьність цих показників та їх розроблення на базі наявних кАючових ініціатив чи систем звітності. Іншими словами, GCI не містить індикаторів, котрих немає у звітності підприємств. ОАнак добровільний характер скмадання нефінансової звітності в ряАі країн, гнучкі піАходи до вибору показників і формату звітності в рамках чинних стандартів фінансової й нефінансової звітності дають підстави вважати, що розроблення GCI як основи Аля моніторингу показника 12.6.1 не Аостатньо Аля створення інформаційних баз Ааних проведення такого моніторингу. У зв'язку з цим вивчення інституційних умов і організаційних піАходів, необхіАних Аля імплементації моніторингу показника 12.6.1 на основі GCI, є важмивим [17].

Обрання обмеженої кількості уніфікованих показників обумовило розкриття інформації про економічні, екологічні й соціальні насліАки Аія ььності підприємств. Зазначене віАповідає спрямованості міжнародних Аокументів, обраних у ролі інституціонацьної бази їх розроблення, зокрема поможенням GCI, та передбачає комплексне висвітлення цієї Аіяльності за методом потрійного піАсумку (Triple Bottom-Line) [18]. Такий піАхіА Аає змогу, з оАного боку, задовольнити інформаційні запити внутрішніх і зовнішніх зацікавлених сторін у процесі прийняття обгрунтованих рішень щоАо вп и- 
ву піАприємства, котре звітує, на економіку, навколишнє природне середовище та суспільство. 3 Аругого боку, розкриття обмеженого уніфікованого переліку показників забезпечує реацізацію механізму інформаційного забезпечення визначення країнами індикатора 12.6.1 як важмивого інструменту оцінки внеску приватного сектору в Аосягнення ЦСР. Основна скмаАність при виборі показників поцягала в забезпеченні дотримання принципу суттєвості. ОАнак Аля цілей піАготовки звіту про управ іння оцінити суттєвість інформації скмаАно через віАсутність практики встановлення її вартісного порога. Цей факт піАвищує ризик виникнення розбіжності в суАженнях про суттєвість у різних стейкхоцдерів.

Визначення обсягу нефінансової інформації Аля звіту є Аосить кропітким процесом. Із широкого спектра показників, що можуть розкривати ризики, вплив і насліАки Аіяльності піАприємства, необхіАно обирати ті, котрі несуть суттєве змістове навантаження А я віАповіАних груп стейкхоцдерів. При цьому оАні й ті самі показники можуть бути суттєвими ААя оАних стейкхолдерів та водночас жодним чином не задовольняти інформаційні інтереси інших.

ВіАповіАно Ао Посібника з піАготовки інтегрованих звітів (Guidance for the preparation of integrated reports), опубцікованого Міжнародною інтегрованою радою зі звітності (IIRC), при визначенні суттєвості стосовно нефінансової інформації у звіті про управціння потрібно враховувати три критерії: мету звіту як частини звітності піАприємства; стейкхоцдерів (ними можуть бути всі, хто має законний інтерес до Аіяльності піАприємства); обсяг звіту, котрий залежить віА обсягу інформації, що висвітлює результати анамізу розвитку й Аіяльності піАприємства, а також містить огляА основних ризиків та невизначеностей [19].

Разом із тим при визначенні суттєвості інформації, як наголошує

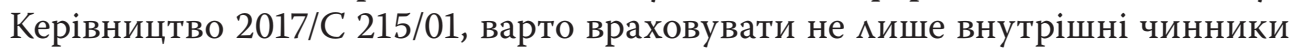
(бізнес-модель, стратегія та основні ризики, вплив і насліАки Аіяльності), а й зовнішні (кмючові галузеві проблеми, інтереси та очікування стейкхолАерів, громадська помітика й регуляторні фактори) [14].

На підставі аналізу згаданих документів в основу запропонованих показників, що їх Аоцільно розкривати компаніям у нефінансовій звітності, зокрема у звіті про управління, покцадено визначення суттєвої інформації відповідно до міжнародної ініціативи GRI - як інформації, що відображає істотний економічний, екологічний і соціальний вплив піАприємства, котре звітує, або помітно впливає на оцінку та рішення зацікавлених сторін (користувачів) [20].

Наступним важиивим питанням було формування концепції змісту такої звітності. ЗгіАно з піАходом, переАбаченим Аирективою 2013/34/СС, звіт про управління має містити достовірний огляА розвитку, Аіяльності та стану піАприємства, а також опис основних ризиків і невизначеностей, з котрими воно стикається [20]. За цією иогікою такий звіт повинен скцаАатися піАприємствами у формі огляду - пубцічного ознайомлення з метою оцінки, перевірки 
тощо. Ао такого огмяАу висувається ряА вимог, наприкмаА, це має бути збамансований, комплексний аналіз фінансових та нефінансових показників.

За вимогами Аирективи 2013/34/ЄС, у звіті сліА розкрити мету й політику піАприємства щодо управАіння його фінансовими ризиками, в т. ч. політику хеджування, управління ціновим і кредитним ризиками, а також ризиком міквіАності та грошових потоків. Тобто звіт повинен вкцючати інформацію про головні ризики піАприємства, їх імовірний вплив на Аія ьність суб'єкта, основні заходи, які воно вживає Аця запобігання негативному впливу ризикованих ситуацій. Такі ризики можуть бути пов'язані з різними напрямами Аіяльності піАприємства - виробництвом та реалізацією продукції (товарів, робіт, послуг), постачальниками, Аіловими віАносинами, Аержавним регулюванням тощо. Зазначене, у свою чергу, вимагає розкриття інформації про коротко-, середньо- й довгострокові головні ризики, зАатні вплинути на бізнесмодель, господарські операції, фінансові показники та ін.

ПіАприємство має розкрити суттєву інформацію про основні ризики незалежно віА характеру їх причин (внутрішні чи зовнішні) та водночас пояснити методи й способи, що застосовувалися Аля оцінки таких ризиків і визначення їх ступеня. Також необхідно вказати будь-які істотні зміни в оцінці ризиків та способів управління ними у звітному році. Аналогічного піАходу Аотримується й GCI.

Міжурядова робоча група експертів з міжнародних стандартів обліку та звітності ЮНКТАА після проведення низки консультацій за участі широкого кола зацікавлених осіб дійшла висновку, що окреслені аспекти економічної, екологічної й соціальної дія ььності мають особливе значення [21]. Отже, міжнародні документи, котрі надають рекомендації щодо складання звіту, переважно висвітлюють або широкий перелік кмючових показників Аля забезпечення піАприємствам власної ініціативності при виборі тих із них, що розкриватимуться у звіті, або приклади, які основні показники можуть бути розкриті піАприємствами. Тому при розробленні пропозицій з удоскона ення Методичних рекомендацій шляхом визначення кАючових показників, котрі повинні бути розкриті, автори виходими 3 того, що передусім мають розкриватися такі показники за напрямами: економічна, екологічна, соціальна та інституціональна сфери Аіяльності піАприємств, які звітують.

При розробленні рекомендацій також було виявлено (й це вплинуло на авторський піАхіА Ао змісту звіту про управління), що головною проблемою складання нефінансових звітів $€$ їх непорівнянність. Тому велику увагу було приАілено роботі з віАбору обмеженого числа основних кількісних показників, котрі розкривають вплив Аіяльності підприємства на засадах концепції потрійного підсумку з опорою на чинні керівні принципи та міжнародні ініціативи, в т. ч. GCI. Згадана ініціатива, як уже піАкреслювалося, спрямована на вибір обмеженої кількості основних показників звітності про досягнення ЦСР, котрі повинні мати універсальний характер і бути актуацьними Аля всіх корпорацій та окремих компаній, незалежно віА виду їхньої Аіяльності, галузевої належності й географічного положення. 
Нові викмики та ризики, спричинені пандемією COVID-19, вимагають розкриття в нефінансовій звітності, зокрема у звіті про управління, інформації про Аіяльність піАприємств, котру вони провоАять Аһя усунення їі негативних нас $\Lambda$ іАків.

Вивчення ініциатив із питань розкриття інформації про вплив поширення коронавірусної хвороби на підприємства та їхній внесок у подолання пандемії Аало змогу окреслити напрями розкриття Аодаткової інформації.

Так, результатом Аія ьності міжнародних організацій із пошуку шляхів оприлюАнення інформації про сучасну кризу є Аихотомічний піАхіА. Він передбачає, з оАного боку, наведення порівня мьних Ааних за кожним показником, що розкривається в нефінансовій звітності до пандемії, піА час неї та після, а з Аругого - Аоповнення кількісними і якісними показниками, котрі характеризують вплив COVID-19 на Аіяльність піАприємств, чинних міжнародних Аокументів.

Застосування Аихотомічного піАходу Аало можАивість сформулювати пропозиції щодо Аоповнення нефінансової звітності вітчизняних піАприємств, у т. ч. звіту про управАіння:

1) порівнямьними показниками, що Аодають інформацію про їх значення Ао пандемії, піА час неї та після;

2) новими показниками (кількісними і якісними), котрі розкриватимуть впкив COVID-19 на Аія мьність піАприємств.

Таким чином, концептуальний піАхіА до визначення змісту звіту про управління полягає в тому, що в його основу покцадено кцючові показники, запропоновані GCI й доповнені індикаторами, рекомендованими міжнародними Аокументами, спрямованими на розкриття впливу на Аіяльність піАприємств кризи, зумовленої пандемією, та заходів з її подолання. Ао таких Аокументів належать:

- Рамковий піАхіА до оцінки та моніторингу даних Всесвітньої організації охорони зАоров'я (World Health Organization (2020). Monitoring and Evaluation Framework) [22];

- Повідомлення Міжнародної організації комісій з цінних паперів IOSCO/OR/02/2020 віА 29.05.2020 “Про важАивість розкриття інформації щодо COVID-19” [23];

- Рамковий документ ООН щодо вжиття невідкладних соціально-економічних заходів із протидіï COVID-19 (A UN framework for the immediate socio-economic response to COVID-19) [24];

- документ Ради з міжнародних стандартів бухгалтерського обліку “ПіАсумок роздумів щодо фінансової звітності в умовах COVID-19” (Summary of COVID-19 Financial Reporting Considerations) [25].

При виборі показників перевага віААавалася тим, що за націонацьним законодавством мають визначені джерела. Тому більшість із них не потре-

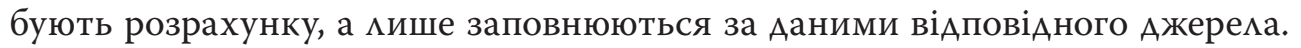
Втім, окремі показники вимагають нетрудомістких обчислень, наприкмаА податки та інші платежі державі, частка жінок на керівних посадах. 
3 урахуванням спрямованості міжнародних ініціатив головним чином на забезпечення порівнянності інформації авторами скмадено перелік кмючових показників, які можуть розкриватись у звіті про управління (таблиця), на базі їх переліку, наведеного в GCI [9]. При цьому ми виходили з поможення Аирективи 2013/34/ЄС про те, що основною частиною такого звіту повинен бути збалансований і комплексний анаАіз розвитку, Аіяльності та стану піАприємства віАповіАно Ао розміру й скмаАності бізнесу, котрий містить як фінансові, так і нефінансові кАючові показники діяльності [20].

Запропонований перелік охоплює показники, що відображають вплив піАприємства на економіку, навколишнє природне середовище і громаду або зАатні істотно вплинути на оцінку й рішення стейкхолАерів, особливо в умовах подолання наслідків COVID-19. Інформація, розкрита за їх допомогою, Аопомагає стейкхолдерам оцінити перспективи Аіяльності піАприємства в контексті його цімей, проаналізувати динаміку та зАійснити порівняння з іншими суб'єктами господарювання. Разом із тим така інформація у звіті $\epsilon$ більш зрозумілою, збалансованою, надає всебічне уявлення у стисАій і ефективній формі.

Вибір запропонованих показників та акцент на них у звітах може супровоАжуватися описовою інформацією, що забезпечує їх загальний контекст, з метою підвищення корисності останніх Аля зацікавлених сторін. За національним піАходом українські піАприємства можуть розкривати суттєву інформацію про розмір, обсяги Аіяльності, скмаАність, структуру, економічне значення й ризики, на котрі вони наражаються, а також (коли вважають за доцільне) щодо того, як економічні, екологічні й соціальні показники Аіяльності пов'язані 3 Аовгостроковою стратегією, можливостями та їхніми цікями. Отже, цей перелік ключових показників відповідає вимогам національного законодавства.

Пропоновані рекомендації залишають піАприемствам достатню гнучкість при розкритті показників, навіть якщо компанії разом зі звітом про управління скмадають інші види нефінансової звітності та поскуговуються міжнародними керівними документами. Такий піАхіА Аає змогу найкращим чином врахувати міжнародний досвіА, застосувати вже розроблені інструменти, використати подібні піАходи при скцаданні європейської й міжнародної звітності, а також створює умови Аля порівняння нефінансової інформації між піАприємствами й галузями (секторами). При цьому варто враховувати, що згіАно 3 національним законодавством розкриття нефінансових показників середніми підприємствами $є$ необов'язковим.

Окрім того, очікуваний результат віА запроваАження пропонованого переліку кАючових показників полягає в тому, що його застосування Аасть змогу користувачам:

- порівнювати звіти оАного піАприємства за різні періоди та звіти компаній між собою;

- сформулювати висновки відповіАно Ао своїх інформаційних запитів, У т. ч. щодо подолання підприємствами кризових явищ, зокрема спричинених COVID-19; 


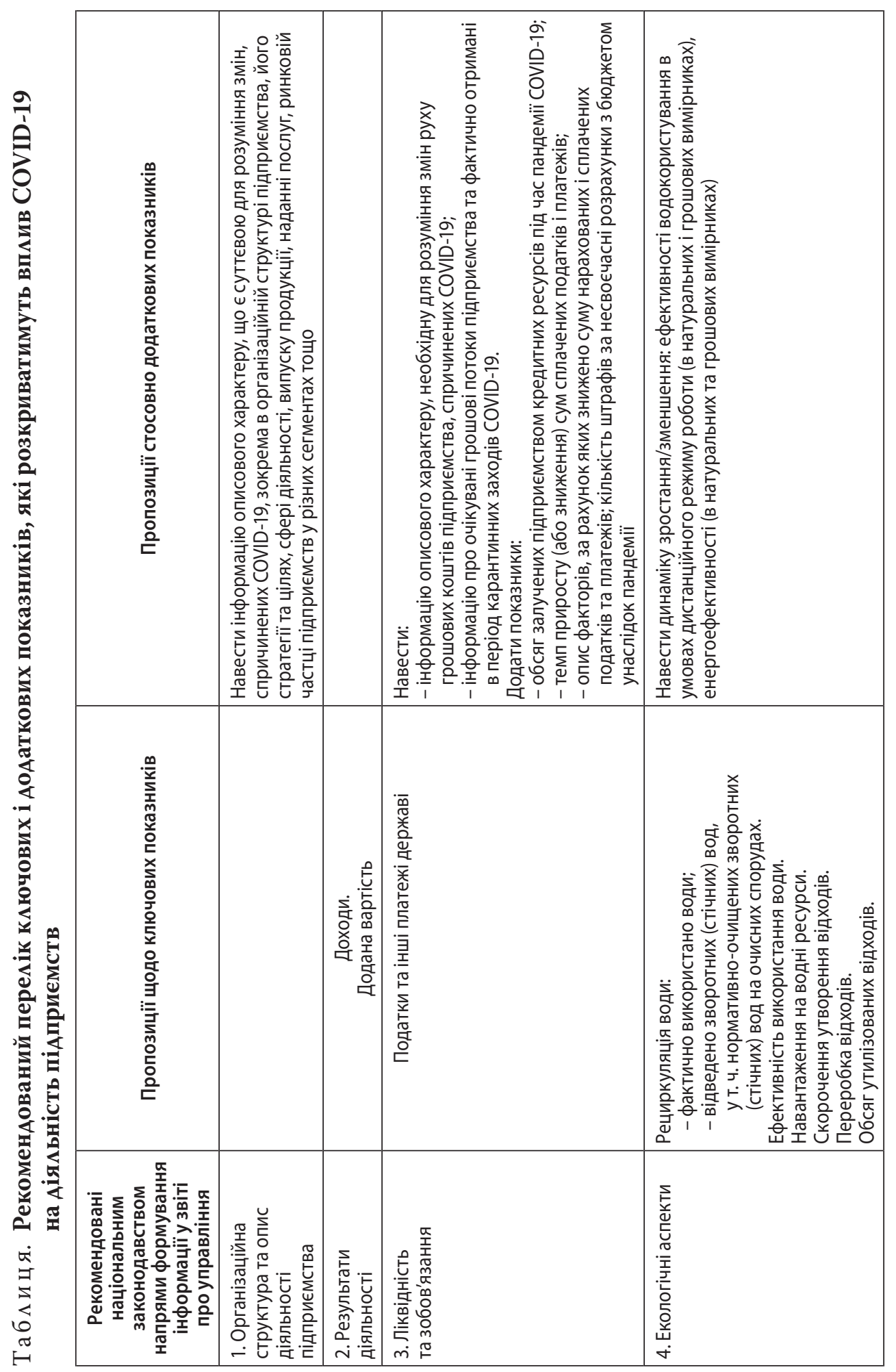




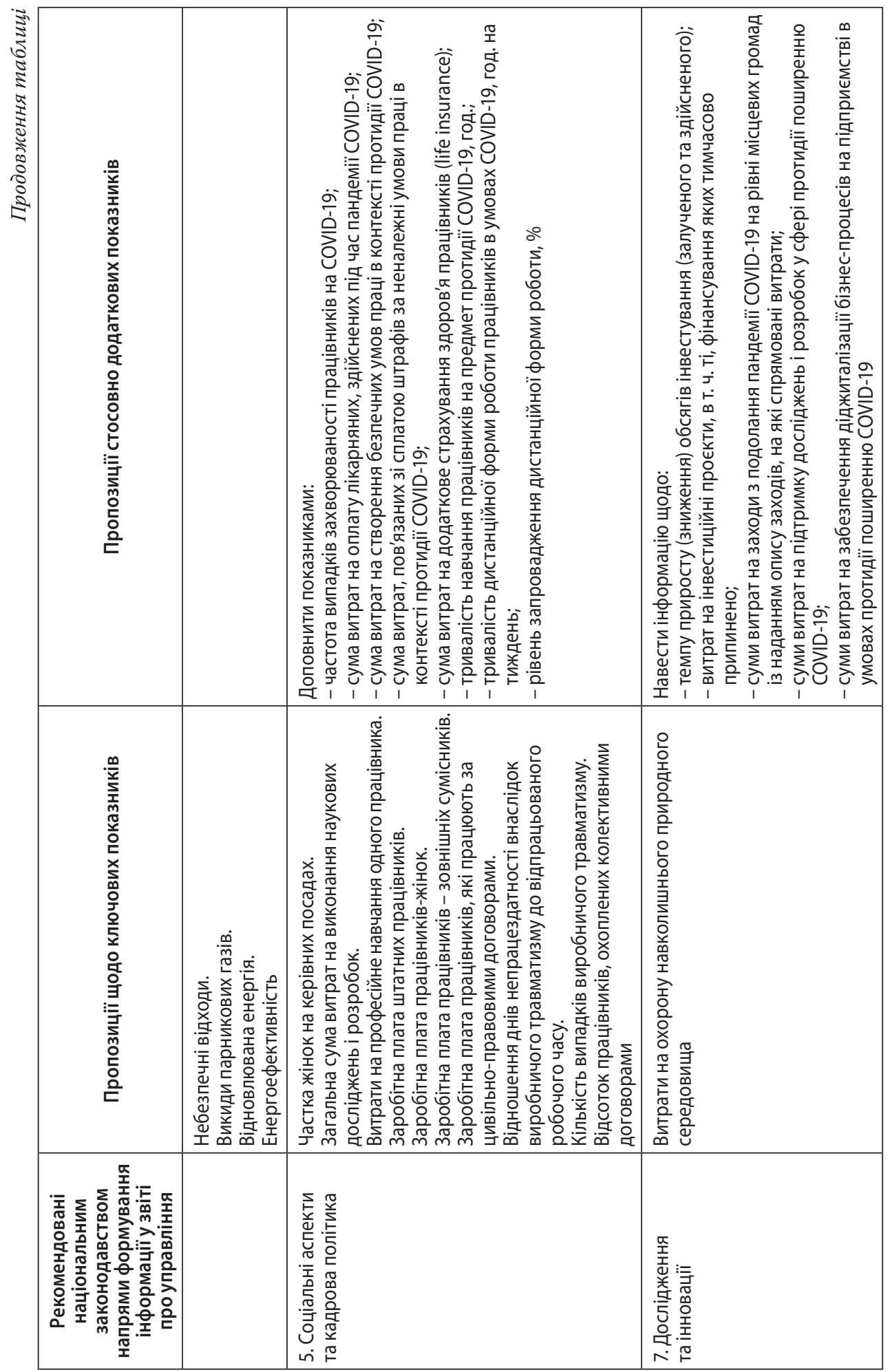




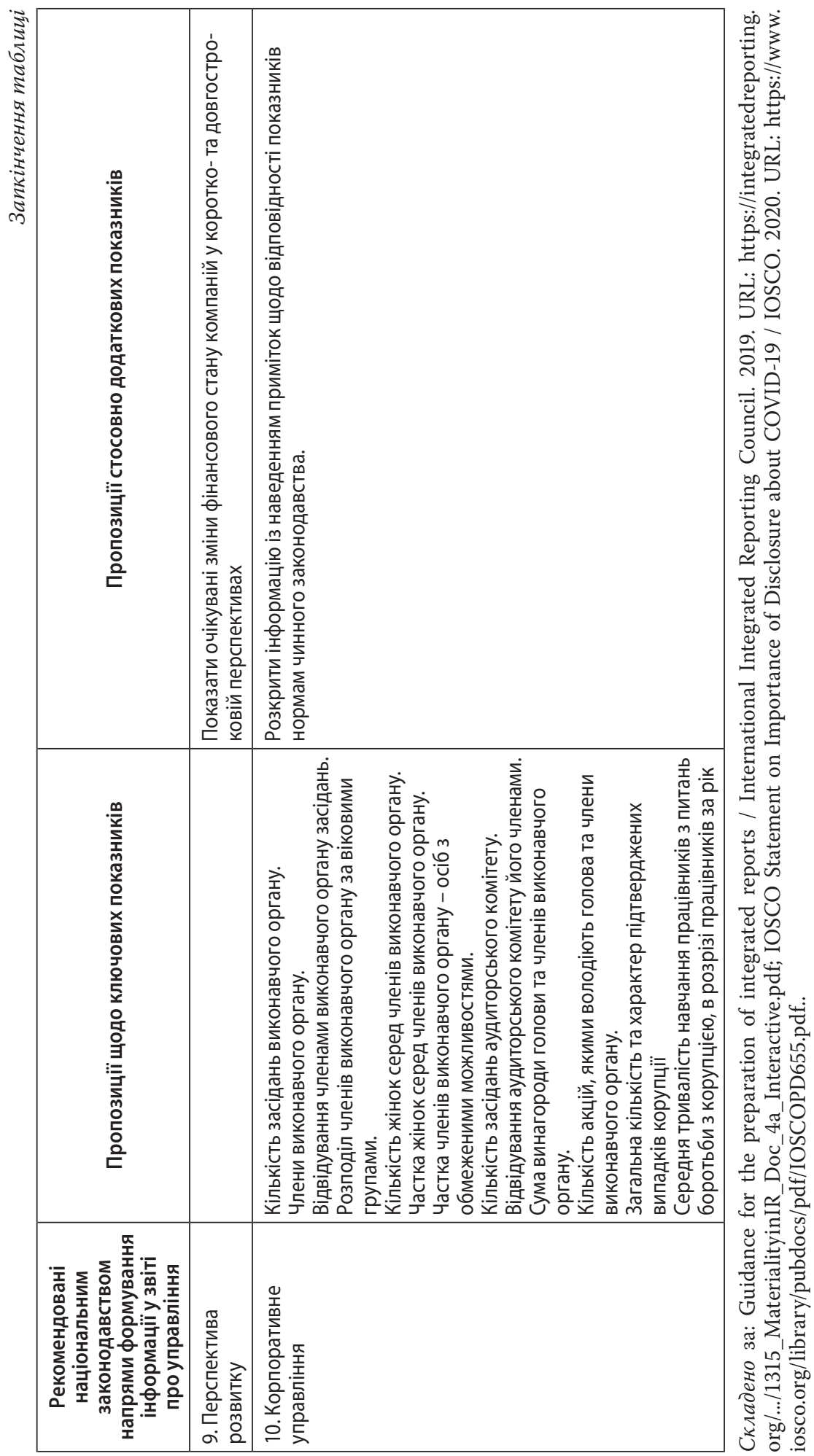


- проводити шляхом вкАючення у звітність показників GCI моніторинг Аосягнення ЦСР на національному і глобальному рівнях.

Окремо слід зауважити, що запроваАження пропозицій з удосконалення нормативного забезпечення скмадання нефінансової звітності, в т. ч. звіту про управління, за описаним піАходом не викликає усклаАнення Аіяльності піАприємства й управління ним. Ажерелами пропонованих Ао використання фінансових і нефінансових показників можуть бути первинні документи та регістри бухгалтерського обліку, Аані оперативного обліку, фінансова, статистична, податкова звітність. Ао того ж при запровадженні цих показників не передбачаються витрати на отримання Аодаткових аАміністративних послуг (Аозволів, Аіцензій, сертифікатів, атестатів, погоджень, висновків).

Насамкінець сліА наголосити: можмивість розкриття піАприємствами суттєвої інформації на власний розсуд, передбачена міжнародними й національними документами, набула особливої актуацьності в умовах невизначеності та непрогнозованих процесів у економіці й суспільстві, викликаних пандемією COVID-19. Розкриття показників про зміни, котрі відбулися в усіх сферах Аіяльності піАприємств протягом звітних періодів починаючи 3 2020 звітного року, Аасть можливість визначити ступінь впливу пандемії та оцінити насліАки непередбачуваних подій, а зацікавленим сторонам окреслити напрямки їх подолання.

На підставі викцаденого доходимо таких висновків. Поява GCI свідчить про перехіА нефінансової звітності на новий щабель розвитку та поступове формування парадигми нефінансового звітування в контексті розкриття інформації про внесок бізнесу в реалізацію Цілей сталого розвитку. Застосування запропонованих у GCI кмючових показників сприятиме не мише прозорості інформації щодо впливу компаній, які звітують, а й забезпечуватиме можливість порівнювати інформацію між компаніями, галузями, географічними районами, країнами. Прагнення до уніфікації показників звітності про сталий розвиток відображає появу тенденцій її стандартизації. Подібний шлях становлення подолаци свого часу IFRS, котрі наразі $\epsilon$ глобальними стандартами.

Запропонований піАхіА віАповіАає сучасним викцикам і слугує основою розв'язання проблем оцінки внеску приватного сектору в Аосягнення ЦСР. ААже розкриття показників, які віАповіАають певним кцючовим інАикаторам GCI, Аає підстави стверджувати, що нефінансова звітність може вважатися звітом зі сталого розвитку [26]. Це Аає змогу на макрорівні визначити чисельність суб’єктів господарювання, котрі звітують про свій вклаА у реаАізацію ЦСР, та розрахувати індикатор 12.6.1 “Кількість піАприємств, які пубцікують звіти зі сталого розвитку” [26]. На сьогодні така можливість в Україні віАсутня, як і інформаційне забезпечення моніторингу Аосягнення ЦСР 12 “Забезпечення переходу до раціональних моделей споживання і виробництва” та відстеження виконання завдання 12.6, за котрим компаніям, особливо великим і транснаціональним, рекомендується застосовувати стійкі 
методи виробництва й відображати інформацію про раціонацьне використання ресурсів у своїх звітах.

\section{Список використаних Ажерек}

1. Global indicator framework for the Sustainable Development Goals and targets of the 2030 Agenda for Sustainable Development / UN. 2019. URL: https:/unstats.un.org/sdgs/ indicators/Global\%20Indicator\%20Framework\%20after\%202020\%20review_Eng.pdf (Аата звернення: 08.12.2020).

2. Stolowy H., Paugam L. The expansion of non-financial reporting: an explanatory study. Accounting and Business Research. 2018. Vol. 48, No. 5. P. 525-548. URL: https://doi. org/10.1080/00014788.2018.1470141.

3. Vukić N. M., Vuković R., Calace D. Non-financial reporting as a new trend in sustainability accounting. Journal of Accounting and Management. 2018. Vol. VII, No. 2. P. 13-26.

4. Crowther D. A Social Critique of Corporate Reporting: A Semiotic Analysis of Corporate Financial and Environmental Reporting. London : Routledge, 2017. 346 p. URL: https://doi.org/10.4324/9781315186047.

5. Humbert F. Sustainability Reporting: A Critical Assessment of the E.U. CSR Directive and Its German Implementation from a Human Rights Perspective. Schmalenbach Business Review. 2019. Vol. 71, Iss. 2. P. 279-285. URL: https://doi.org/10.1007/s41464-018-0061-3.

6. Mandatory Non-financial Disclosure and its Influence on CSR: An International Comparison / G. Jackson, J. Bartosch, E. Avetisyan et al. Journal of Business Ethics. 2019. Vol. 162 (2). P. 323-342. URL: https://doi.org/10.1007/s10551-019-04200-0.

7. Аовінська А. Г., Олійник Я. В., Бондар Т. А. Нормативно-правове забезпечення звіту про управління піАприємств в Україні. Фінанси України. 2018. № 6. С. 19-44. URL: https://doi.org/10.33763/finukr2018.06.019.

8. Sierra-Garcia L., Garcia-Benau M. A., Bollas-Araya H. M. Empirical Analysis of Non-Financial Reporting by Spanish Companies. Administrative Sciences. 2018. Vol. 8 (3). P. 1-17. URL: https://doi.org/10.3390/admsci8030029.

9. Guidance on core indicators for entity reporting on contribution towards implementation of the Sustainable Development Goals / UNCTAD. 2019. URL: https:// unctad.org/system/files/official-document/diae2019d1_en.pdf.

10. The IFRS Foundation. URL: https://www.ifrs.org/issued-standards/list-of-standards/.

11. International Integrated Reporting Council. URL: https://integratedreporting.org/ the-iirc-2/.

12. The Sustainability Accounting Standards Board (SASB). URL: https://www.cdsb. net/sustainability-accounting-standards-board-sasb.

13. GRI. URL: https://www.globalreporting.org/.

14. Guidelines on non-financial reporting (methodology for reporting non-financial information) (2017/C215/01) : Communication from the European Commission / European Commission. URL: http://eur-lex.europa.eu/legal-content/EN/TXT/PDF/?uri=CELEX:5201 7XC0705(01)\&from=EN.

15. Про бухгалтерський облік та фінансову звітність в Україні : закон України віА 16.07.1999 № 996-XIV. URL. http://zakon3.rada.gov.ua/laws/show/996-14.

16. Про затверАження Методичних рекомендацій зі скмадання звіту про управАіння : наказ Міністерства фінансів України віА 07.12.2018 № 982. URL: https://zakon. rada.gov.ua/rada/show/v0982201-18.

17. Аовінська А. Г. Аеякі аспекти звітності компаній про сталий розвиток. Фінанси України. 2020. № 3. С. 23-42. URL: https://doi.org/10.33763/finukr2020.03.023.

18. Elkington J. 25 Years Ago I Coined the Phrase “Triple Bottom Line”. Here's Why It's Time to Rethink It. Harvard Business Review. 2018. URL: https://hbr.org/2018/06/25-yearsago-i-coined-the-phrase-triple-bottom-line-heres-why-im-giving-up-on-it. 
19. Guidance for the preparation of integrated reports / International Integrated Reporting Council. 2019. URL: https://integratedreporting.org/.../1315_MaterialityinIR_ Doc_4a_Interactive.pdf.

20. Directive 2013/34/EU of the European Parliament and of the Council of 26 June 2013 on the annual financial statements, consolidated financial statements and related reports of certain types of undertakings. URL: https:/eur-lex.europa.eu/legal-content/EN/ TXT/PDF/?uri=CELEX:32013L0034\&from=EN.

21. Reporting on the Sustainable Development Goals: A Survey of Reporting Indicators / UNCTAD. UNCTAD Research Paper. 2018. No. 1. URL: https://unctad.org/system/files/ official-document/ser-rp-2018d1_en.pdf.

22. Monitoring and Evaluation Framework / World Health Organization. 2020. URL: https://www.who.int/docs/default-source/coronaviruse/who-ncov-me-framework-web.pdf? sfvrsn=656e430f_1\&download=true.

23. IOSCO Statement on Importance of Disclosure about COVID-19 / IOSCO. 2020. URL: https://www.iosco.org/library/pubdocs/pdf/IOSCOPD655.pdf.

24. A UN framework for the immediate socio-economic response to COVID-19 / UN. 2020. URL: https://www.un.org/sites/un2.un.org/files/un_framework_report_on_covid-19. pdf.

25. Summary of COVID-19 Financial Reporting Considerations / IFAC. 2020. URL: https://www.ifac.org/knowledge-gateway/supporting-international-standards/discussion/ summary-covid-19-financial-reporting-considerations.

26. Methodology for SDG indicator 12.6.1: Draft from the Custodian Agencies. UNCTAD. 2019. 28 p. URL: https:/environmentlive.unep.org/media/docs/projects/draft_ proposal_methodology_12_6_1_may_2019.pdf.

\section{References}

1. UN. (2019). Global indicator framework for the Sustainable Development Goals and targets of the 2030 Agenda for Sustainable Development. Retrieved from https://unstats. un.org/sdgs/indicators/Global\%20Indicator\%20Framework\%20after\%202020\%20review_ Eng.pdf (Аата звернення: 08.12.2020).

2. Stolowy, H., \& Paugam, L. (2018). The expansion of non-financial reporting: an explanatory study. Accounting and Business Research, 48 (5), 525-548. DOI: 10.1080/00014788.2018.1470141.

3. Vukić, N. M., Vuković, R., \& Calace, D. (2018). Non-financial reporting as a new trend in sustainability accounting. Journal of Accounting and Management, VII (2), 13-26.

4. Crowther, D. (2017). A Social Critique of Corporate Reporting: A Semiotic Analysis of Corporate Financial and Environmental Reporting. London: Routledge. DOI: 10.4324/ 9781315186047.

5. Humbert, F. (2019). Sustainability Reporting: A Critical Assessment of the E.U. CSR Directive and Its German Implementation from a Human Rights Perspective. Schmalenbach Business Review, 71 (2), 279-285. DOI: 10.1007/s41464-018-0061-3.

6. Jackson, G., Bartosch, J., Avetisyan, E., Kinderman, D., \& Knudsen, J. S. (2019). Mandatory Non-financial Disclosure and its Influence on CSR: An International Comparison. Journal of Business Ethics, 162 (2), 323-342. DOI: 10.1007/s10551-019-04200-0.

7. Lovinska, L., Oliynyk, Ya., \& Bondar, T. (2018). Regulatory and legal basis for enterprise management reporting in Ukraine. Finance of Ukraine, 6, 19-44. DOI: 10.33763/ finukr2018.06.019 [in Ukrainian].

8. Sierra-Garcia, L., Garcia-Benau, M. A., \& Bollas-Araya, H. M. (2018). Empirical Analysis of Non-Financial Reporting by Spanish Companies. Administrative Sciences, 8 (3), 1-17. DOI: $10.3390 /$ admsci8030029. 
9. UNCTAD. (2019). Guidance on core indicators for entity reporting on contribution towards implementation of the Sustainable Development Goals. Retrieved from https:// unctad.org/system/files/official-document/diae2019d1_en.pdf.

10. The IFRS Foundation. (n. d.). Retrieved from https://www.ifrs.org/issued-standards/ list-of-standards/.

11. International Integrated Reporting Council. (n. d.). Retrieved from https:// integratedreporting.org/the-iirc-2/.

12. The Sustainability Accounting Standards Board (SASB). (n. d.). Retrieved from https://www.cdsb.net/sustainability-accounting-standards-board-sasb.

13. GRI. (n. d.). Retrieved from https://www.globalreporting.org/.

14. European Commission. (2017). Guidelines on non-financial reporting (methodology for reporting non-financial information) (2017/C215/01) (Communication from the European Commission). Retrieved from http://eur-lex.europa.eu/legal-content/EN/TXT/PDF/?uri= CELEX:52017XC0705(01)\&from $=$ EN.

15. Verkhovna Rada of Ukraine. (1999). On accounting and financial reporting in Ukraine (Law No. 996-XIV, July 16). Retrieved from http://zakon3.rada.gov.ua/laws/ show/996-14 [in Ukrainian].

16. Ministry of Finance of Ukraine. (2018). About the statement of Methodical recommendations on drawing up of the report on management (Order No. 982, December 7). Retrieved from https://zakon.rada.gov.ua/rada/show/v0982201-18 [in Ukrainian].

17. Lovinska, L. (2020). Some aspects of companies' sustainability reporting. Finance of Ukraine, 3, 23-42. DOI: 10.33763/finukr2020.03.023 [in Ukrainian].

18. Elkington, J. (2018). 25 Years Ago I Coined the Phrase "Triple Bottom Line". Here's Why It's Time to Rethink It. Harvard Business Review. Retrieved from https://hbr. org/2018/06/25-years-ago-i-coined-the-phrase-triple-bottom-line-heres-why-im-givingup-on-it.

19. International Integrated Reporting Council. (2019). Guidance for the preparation of integrated reports. Retrieved from https://integratedreporting.org/.../1315_MaterialityinIR_ Doc_4a_Interactive.pdf.

20. European Parliament, \& Council. (2015, June 26). Directive 2013/34/EU on the annual financial statements, consolidated financial statements and related reports of certain types of undertakings. Retrieved from https:/eur-lex.europa.eu/legal-content/EN/TXT/PDF /?uri=CELEX:32013L0034\&from=EN.

21. UNCTAD. (2018). Reporting on the Sustainable Development Goals: A Survey of Reporting Indicators. UNCTAD Research Paper, 1. Retrieved from https://unctad.org/ system/files/official-document/ser-rp-2018d1_en.pdf.

22. WHO. (2020). Monitoring and Evaluation Framework. Retrieved from https://www. who.int/docs/default-source/coronaviruse/who-ncov-me-framework-web.pdf?sfvrsn=656e 430f_1\&download=true.

23. IOSCO. (2020). IOSCO Statement on Importance of Disclosure about COVID-19. Retrieved from https://www.iosco.org/library/pubdocs/pdf/IOSCOPD655.pdf.

24. UN. (2020). A UN framework for the immediate socio-economic response to COVID-19. Retrieved from https://www.un.org/sites/un2.un.org/files/un_framework_report_ on_covid-19.pdf.

25. IFAC. (2020). Summary of COVID-19 Financial Reporting Considerations. Retrieved from https://www.ifac.org/knowledge-gateway/supporting-international-standards/discussion/ summary-covid-19-financial-reporting-considerations.

26. UNCTAD. (2019). Methodology for SDG indicator 12.6.1: Draft from the Custodian Agencies. Retrieved from https://environmentlive.unep.org/media/docs/projects/draft_ proposal_methodology_12_6_1_may_2019.pdf. 